\title{
VIDEO SEBAGAI E-PORTFOLIO MAHASISWAUNTUK MENINGKATKAN KETERAMPILAN MAHASISWA
}

\author{
Giandari Maulani ${ }^{1}$ \\ Untung Rahardja ${ }^{2}$ \\ Lalita Tri Adila ${ }^{3}$ \\ Alumni Universitas Budi Luhur Program Studi Magister Komputer ${ }^{1}$, Alumni Universitas \\ Indonesia Program Studi Magister Teknologi Informasi ${ }^{2}$, Mahasiswa STMIK ${ }^{3}$ \\ Jl. Jendral Sudirman No.40, Modernland, Tangerang \\ Email:dewi.immaniar@raharja.info1); untung@raharja.info2); lalita@raharja.info3)
}

Diterima:18 Januari 2015/ Disetujui : 3 Februari 2015

\begin{abstract}
The development of science and technology information in the era of globalization so advanced. This phenomenon results in a change in all aspects of life, including one of them is the educational aspect. The use of technology in education is done in order to improve the efficiency and effectiveness of the learning process. However, the growing use of technology is not widely used lecturers to change the way student assessment. Student assessment is focussed on learning outcomes not only of the process of change as a result of the student's ability to learn. the use of portfolios also require adequate storage space and requires no small cost. Therefore we need a valuation technique that directs faculty to assess student skills or psychomotor aspects. By using the technique of portfolio assessment with the use of the video as a result be able to answer all the problems that exist. This journal will discuss how assessment techniques, portfolio assessment, the transition of the portfolio into an e-portfolio, the use of video as a medium of e--portfolio also discusses the problems encountered in the portfolio assessment. Besides, there are advantages and disadvantages of the use of video as a medium of e--portfolio. In the implementation of this journal featuring two case studies of e--portfolio with student video uploaded on YouTube and shown in the playlist in Magics Channel owned Perguruan Tinggi Raharja
\end{abstract}

keyword: video, e-portfolio, skills, Magics Channel

\section{ABSTRAK}

Perkembangan ilmu pengetahuan dan teknologi informasi pada era globalisasi maju dengan begitu pesat. Fenomena ini mengakibatkan perubahan dalam segala aspek kehidupan termasuk salah satunya adalah aspek pendidikan. Pemanfaatan teknologi dalam dunia pendidikan dilakukan dalam rangka meningkatkan efisiensi dan efektifitas proses pembelajaran. Namun, pemanfaatan teknologi yang berkembang tidak banyak dimanfaatkan para dosen untuk mengubah cara penilaian siswa. Penilaian siswa masih terfokuskan pada hasil belajar semata bukan dari proses perubahan kemampuan siswa sebagai hasil belajar. Penggunaan portofolio juga memerlukan tempat penyimpanan yang memadai dan membutuhkan biaya yang tidak sedikit. Oleh karena itu dibutuhkan suatu teknik penilaian yang mengarahkan dosen untuk menilai mahasiswa dari aspek keterampilan atau psikomotorik. Dengan menggunakan teknik penilaian portofolio dengan memanfaatkan video sebagai hasilnya dapat menjawab semua permasalahan yang ada. Jurnal ini akan membahas bagaimana teknik penilaian, penilaian portofolio, transisi dari portofolio menjadi e--portfolio, pemanfaatan video sebagai media e--portfolio juga 
membahas tentang masalah yang dihadapi dalam penilaian portofolio. Disamping itu terdapat kekurangan dan kelebihan dari penggunaan video sebagai media e--portfolio. Pada implementasinya jurnal ini menampilkan dua studi kasus e--portfolio dengan video yang diunggah mahasiswa di YouTube dan ditampilkan dalam playlist di Magics Channel yang dimiliki Perguruan Tinggi Raharja.

Kata kunci: Video, e-portfolio, keterampilan, Magics Channel

\section{PENDAHULUAN}

Seiring dengan perkembangannya ilmu pengetahuan dan teknologi informasi pada era globalisasi yang maju dengan begitu pesat, mengakibatkan perubahan dalam segala aspek kehidupan termasuk salah satunya adalah aspek pendidikan. Pemanfaatan teknologi dalam dunia pendidikan dilakukan dalam rangka meningkatkan dan memajukan efisiensi dan efektifitas proses pembelajaran. Kemajuan pendidikan akan berpengaruh secara signifikan terhadap kemajuan suatu bangsa. Selain itu pendidikan tidak terlepas dalam kehidupan sehari-hari.

Teknik, metode bahkan strategi mengajar yang sudah ada dengan cepat terganti dengan teknik, metode dan strategi yang baru karena dianggap sudah tidak sesuai untuk masih digunakan. Para ahli pendidikan terus berupaya mencari cara-cara baru untuk membuat proses pendidikan semakin maju dan tidak ketinggalan jaman.

Selain teknik, metode dan strategi mengajar yang dengan cepat terganti, teknik penilaian (assesment) pun tidak luput dari perubahan dan peningkatan. Karena penilaian adalah tugas pokok seorang dosen sebagai konsekuensi logis kegiatan pembelajaran yang telah dilaksanakan. Penilaian ini dimaksudkan untuk mengetahui dan mengambil keputusan tentang keberhasilan siswa dalam mencapai kompetensi yang telah ditetapkan. Upaya peningkatan kualitas pembelajaran dapat ditempuh melalui peningkatan kualitas sistem penilaiannya. Karena kualitas pembelajaran dapat dinilai dari hasil penilaiannya.[1]

Ada tiga istilah yang digunakan dan berkaitan dengan penilaian, yaitu tes, pengukuran dan evaluasi (test, measurement and evaluation). Dalam kehidupan sehari-hari orang sering menyamakan pengertian keempat istilah tersebut, padahal keempat istilah tersebut memiliki makna yang berbeda. Beberapa orang juga sering rancu menggunakan istilah--istilah tersebut karena istilah tersebut digunakan untuk merujuk kegiatan yang sama.

Tes (test) merupakan salah satu cara menaksir besarnya kemampuan seseorang secara tidak langsung, yaitu melalui respons seseorang melalui seseorang terhadap stimulus atau pernyataan [2]. Tes merupakan salah satu alat untuk melakukan pengukuran, yaitu alat untuk mengumpulkan informasi karakteristik suatu objek. Objek ini bisa berupa kemampuan peserta didik, sikap, minat, maupun motivasi.Respons peserta tes terhadap sejumlah pertanyaan menggambarkan kemampuan dalam bidang tertentu.Tes merupakan bagian tersempit dari evaluasi.

Pengukuran (measurement) dapat didefinisikan sebagai the process by which information about the attributes or characteristics of thing are determinied and differentiated(Oriondo,1998: 2).[3]. Dengan demikian, esensi dari pengukuran adalah kuantifikasi atau penetapan angka tentang karakteristik atau 
keadaan individu menurut aturan-aturan tertentu. Keadaan individu ini bisa berupa kemampuan kognitif, afektif dan psikomotorik.Pengukuran memiliki konsep yang lebih luas dari pada tes. Kita dapat mengukur karakateristik suatu objek tanpa menggunakan tes, misalnya dengan pengamatan, skala rating atau cara lain untuk memperoleh informasi dalam bentuk kuantitatif.

Evaluasi merupakan suatu proses menyediakan informasi yang dapat dijadikan sebagai pertimbangan untuk menentukan harga dan jasa (the worth and merit) dari tujuan yang dicapai, desain, implementasi dan dampak untuk membantu membuat keputusan, membantu pertanggung jawaban dan meningkatkan pemahaman terhadap fenomena. Menurut rumusan tersebut, inti dari evaluasi adalah penyediaan informasi yang dapat dijadikan sebagai bahan pertimbangan dalam mengambil keputusan.

Penilaian (assessment) memiliki makna yang berbeda dengan evaluasi. Assessment diartikan dalam konteks pendidikan sebagai sebuah usaha secara formal untuk menentukan status siswa berkenaan dengan berbagai kepentingan pendidikan.Popham mendefinisikanassessment dalam kontek pendidikan sebagai konteks usaha secara formal untuk menentukan status siswa berkenaan dengan berbagai kepentingan pendidikan.[4]

Tes, pengukuran, penilaian dan evaluasi bersifat hierarki. Evaluasi didahului dengan penilaian, sedangkan penilaian didahului dengan pengukuran.Salah satu satu alat ukurnya adalah tes.Tes diartikan sebagai alat ukur untuk memperoleh informasi belajar siswa yang memerlukan jawaban atau respon benar atau salah.pengukuran diartikan sebagai kuantifikasi. Penilaian merupakan kegiatan mentafsirkan hasil pengukuran, sedangkan evaluasi merupakan penetapan kualitas program beserta tindak lanjutnya berdasarkan penilaian aspek-aspek program.

berdasarkan uraian diatas hubungan antara tes, pengukuran, penilaian dan evaluasi dapat dibuat dalam bentuk diagram sebagai berikut:

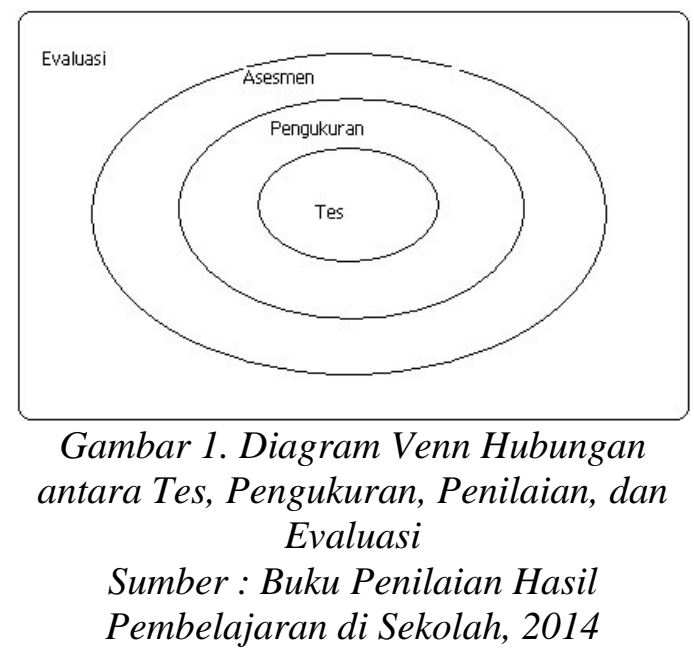

Teknik Penilaian

Penilaian hasil belajar siswa mencakup aspek kompetisi sikap, pengetahuan dan aspek keterampilan yang dilakukan secara berimbang sehingga dapat digunakan untuk menentukan posisi relatif setiap siswa terhadap standar yang telah ditetapkan. Tiap--tiap aspek penilaian (sikap, pengetahuan, dan keterampilan) memiliki karakteristik yang berbeda antara yang satu dengan yang lainnya sehingga memerlukan teknik penilaian yang berbeda yang berbeda. Tidak ada satu teknik penilaian yang terbaik yang sangat digunakan untuk menilai semua aspek kompetensi, karena masing--masing teknik penilaian memiliki kelebihan dan kekurangan. Memerlukan kejelian dan kecerdasan dosen untuk memilih teknik penilaian yang sesuai dengan aspek yang akan diangkat.

Secara garis besar ada sembilan teknik penilaian yang dapat dipilih dosen untuk menilai hasil pembelajaran siswa, 
yaitu: tes, observasi, penilaian diri (self assessment), penilaian antar peserta (peer assessment), penilaian kinerja (performance assessment), penilaian portofolio (portfolio assessment), dan penilaian jurnal (journal assessment). Tiap-tiap teknik penilaian memiliki pengunnaan yang berbeda-beda.Tes lebih cocok digunakan untuk menilai aspek pengetahuan.Observasi, penilaian diri, penilaian antar teman, dan penilaian jurnal lebih cocok digunakan untuk menilai aspek siswa.Penilaian kinerja, penilaian produk, dan penilaian projek dapat digunakn untuk menilai aspek pengetahuan dan keterampilan.Sedangkan penilaian portofolio sangat cocok digunakan untuk menilai aspek keterampilan.

Hubungan antara teknik penilaian dengan aspek penilaian dapat digambarkan dalam tabel berikut.

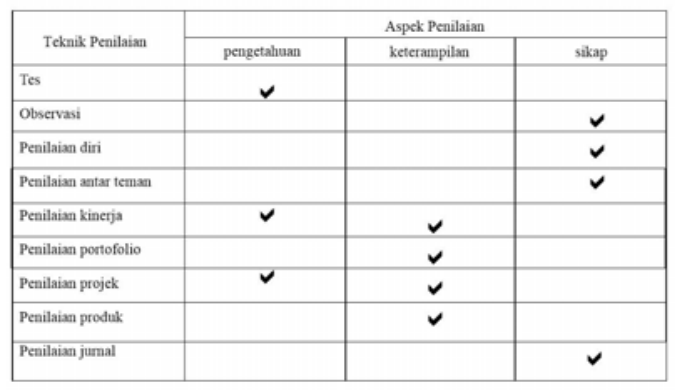

Gambar 2. Tabel Hubungan Teknik

Penilaian dengan Aspek Penilaian

Sumber : Buku Penilaian Hasil

Pembelajaran di Sekolah, 2014

Aspek keterampilan atau psikomotorik sendiri merupakan hasil belajar yang pencapaiannya melibatkan otot dan kekuatan fisik.Dengan kata lain ranah psikomotorik adalah ranah yang berhubungan dengan aktifitas fisik, misalnya lari, melompat, melukis, menari, memukul, mengatik, dan sebagainya.Hasil belajar dalam ranah psikomotorik tampak dalam bentuk-bentuk keterampilan dan kemampuan bertindak individu.

\section{Penilaian Portofolio}

Penilaian portofolio merupakan kegiatan penilaian yang dilakukan dengan menggunakan bukti--bukti hasil belajar (evidence) yang relevan dengan kompetensi keahlian yang dipelajari. Evidence tersebut dapat berupa karya peserta didik (hasil pekerjaan) dari proses pembelajaran yang dianggap terbaik, atau bentuk informasi lain yang terkait dengan kompetensi keahlian tertentu.

Portofolio adalah kumpulan hasil karya seorang peserta didik, sebagai hasil pelaksanaan tugas kinerja, yang ditentukan oleh dosen atau oleh peserta didik bersama dosen, sebagai bagian dari usaha mencapai tujuan belajar, atau mencapai kompetensi yang ditentukan dalam kurikulum. Jadi, tidak setiap kumpulan karya seorang peserta didik disebut portofolio. Portofolio digunakan sebagai instrumen penilaian atau salah satu komponen dari instrumen penilaian, untuk menilai kompetensi peserta didik, atau menilai hasil belajar peserta didik.

Sebagai instrumen penilaian, portofolio difokuskan pada dokumen tentang kerja mahasiswa yang produktif, yaitu 'bukti' tentang apa yang dapat dilakukan oleh mahasiswa, bukan apa yang tidak dapat dikerjakan (dijawab atau dipecahkan) oleh mahasiswa. Bagi dosen, portofolio menyajikan wawasan tentang banyak segi perkembangan siswa dalam belajarnya: cara berpikirnya, pemahamannya atas pelajaran yang bersangkutan, kemampuannya mengungkapkan gagasan--gagasannya, sikapnya terhadap mata pelajaran yang bersangkutan, dan sebagainya.

Portofolio biasanya merupakan hasil karya terpilih dari mahasiswa. Penentuan karya terpilih dari seorang siswa yang dianggap paling baik ditentukan bersama antara dosen dan 
mahasiswa.Dalam penentuan tersebut tentunya harus disepakati kriteria sebuah karya yang dianggap karya yang baik. penyusunan portofolio yang baik mempunyai empat tujuan, yaitu membantu dosen untuk mengakses petumbuhan dan progres siswa, membantu orang tua dan dosen untuk berkomunikasi lebih efektif tentang pekerjaan siswa, membantu dosen dan pembimbing untuk mengevaluasi program instruksi, dan membantu siswa untuk menadi partner dosen dalam proses penilaian.

Terdapat beberapa karakteristik esensial penilaian portofolio, yaitu multi sumber, otentik, dinamis, eksplisit, integrasi, kepemilikan dan beragam tujuan.

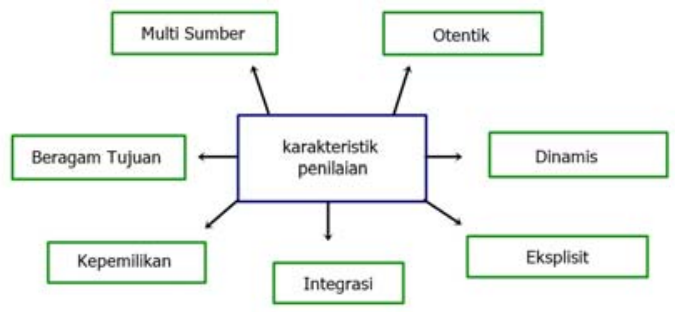

Gambar 3. Karakteristik Penilaian Portofolio Elektronik

Portofolio memiliki tiga bentuk yaitu: (1). Portofolio kerja (working portofolio) , merupakan kumpulan karya yang menggambarkan perkembangan pembuatan karya dari persiapan sampai karya itu selesai. (2). portofolio dokumentasi (documentary portfolio), merupakan koleksi hasil kerja sisa yang khusus digunakan untuk penilaian. (3). portofolio penampilan (show portfolio), adalah kumpulan karya terbaik yang dihasilkan siswa.

\section{Teknik Penilaian Portofolio}

Penilaian portofolio dapat dilaksanakan dengan langkah--langkah sebagai berikut: (a). Jelaskan kepada peserta didik maksud penggunaan portofolio. (b). Jelaskan sampel--sampel portofolio yang dapat digunakan. (c).
Peserta didik diharuskan mengumpulkan dan mengarsipkan portofolio. (d). Cantumkan tanggal pembuatan pada setiap evidence. (e). Tentukan kriteria penilaian sampel--sampel portofolio. (f). Lakukan penilaian diri peserta didik. (g). Lakukan perbaikan terhadap portofolio yang belum sesuai dengan kriteria.

Penilaian portofolio adalah termasuk instrumen non tes. Penafsiran hasil pengukuran instrumen non tes mengikuti aturan pemberian skor beserta klasifikasi hasil penilaian dengan menggunakan skala 3 (Baik (B), Cukup (C) dan Kurang (K)) ,4 (Sangat baik(SB), Baik (B), Cukup (C) dan Kurang (K))dan 5 ((Sangat baik(SB), Baik (B), Cukup (C), Kurang (K) dan Sangat kurang (SK).

Adapun aturan pemberian skor dengan klasifikasi hasil penilaian adalah sebagai berikut: 1 . Skor pernyataan yang negatif kebalikan dari pernyataan yang ideal. 2. Jumlah skor tertinggi ideal = jumlah pernyataan atau aspek penilaian $\mathrm{x}$ jumlah pilihan. 3. Skor akhir $=$ (jumlah skor yang diperoleh : skor tertinggi ideal) $\mathrm{x}$ jumlah kelas interval. 4. jumlah kelas interval $=$ skala hasil penilaian. 5 . Penentuan jarak interval (Ji) diperoleh dengan rumus:

$$
\mathrm{Ji}=(\mathrm{t}-\mathrm{r}) / \mathrm{Jk}
$$

Keterangan: $\mathrm{t}=$ skor tertinggi ideal dalam skala, $\mathrm{r}=$ skor terendah ideal dalam skala dan $\mathrm{Jk}=$ jumlah kelas interval.

\section{e-portfolio}

Untuk itu saat ini portofolio sudah di kembangkan menjadi portofolio elektronik, selanjutnya disingkat $e$-portfolio, adalah koleksi digital artifak-artifak yang merepresentasikan individual, kelompok, komunitas, organisasi, atau institusi (Lorenzo dan Ittelson, 2005). [5] 
Elektronik portofolio (e-portfolio, ePortfolios, efolios, portofolio digital, dll) adalah suatu istilah yang relatif baru, tapi dengan cepat berkembang pada program pendidikan. Karena portofolio elektronik (e--portfolio) telah umumnya digunakan dalam pendidikan guru sebagai sarana untuk: (1) menunjukkan bukti kuat dari pertumbuhan dan kompetensi, berpikir fokus, dan (3) berfungsi sebagai media untuk menerjemahkan teori ke dalam praktek, harapannya adalah bahwa e--portfolio membantu menghubungkan pertumbuhan profesional untuk proses pembelajaran untuk mengajar.

Definisi e-portflio banyak dan berkisar .e-portfolio menggunakan lima kriteria: (1) selektif dan terstruktur koleksi informasi; (2) berkumpul untuk spesifik tujuan dan menunjukkan / bukti; (3) disimpan secara digital dan dikelola oleh perangkat lunak yang sesuai; (4) yang dikembangkan oleh menggunakan multimedia yang tepat dan lazim dalam lingkungan web; dan (5) diambil dari sebuah situs web, atau disampaikan oleh CD-ROM atau DVD [2]. karakteristik ini memungkinkan penulis $e$ portfolio untuk menggabungkan tampilan grafis, video, dan weblinks agar terlihat dinamis. Yang penting dalam karakteristik e-portfolio adalah tujuan untuk mengumpulkan atau mengoleksi bukti otentik dan beragam yang diambil dari arsip yang lebih besar mewakili belajar.

Komponen isie--portfolio juga sangat bervariasi tergantung pada tujuan, bentuk maupun sifat e--portfolio. Secara umum e--portfolio memuat data pribadi yang menggambarkan peserta didik, mata kuliah atau pendidikan informal yang diikuti, kegiatan yang diikuti baik bersifat akademis, sosial, pengalaman berorganisasi maupun bekerja serta prestasi yang dicapai termasuk tulisan, penghargaan, beasiswa dsb.

\section{Video sebagai e-portfolio}

Mahasiswa dapat memanfaatkan berbagai macam media untuk portofolio elektronik. Media berbentuk elektronis berkisar dari penggunaan media kaset audio, video, slide, disket, cd-rom maupun web.

Istilah video begitu sering terdengar ditelinga kita baik itu dari orang yang mengetahui arti dari video itu sendiri ataupun tidak. sering sekali kita menyaksikan video--video di televisi atau di internet. Secara sepintas kita mengetahui istilah video itu berkaitan dengan hiburan.tanpa kita sadari, video adalah media yang sangat menarik untuk dijadikan objek dalam pendidikan. video dapat dikatakan menarik, karena video dapat mengandung dua unsur yaitu audio dan visual. kita dapat menyaksikan video juga disertai suara--suara yang mendukung gambar pada video tersebut.

Video adalah teknologi untuk menangkap, merekam, memproses, mentransmisikan dan menata ulang gambar bergerak. Biasanya menggunakan film seluloid, sinyal elektronik, atau media digital. Video juga bisa dikatakan sebagai gabungan gambar--gambar mati yang dibaca berurutan dalam suatu waktu dengan kecepatan tertentu. Gambar-gambar yang digabung tersebut dinamakan frame dan kecepatan pembacaan gambar disebut dengan frame rate, dengan satu fps.[6]

Menggunakan video sebagai portofolio elektronik dapar memeliki berbagai macam kelebihan. Diantaranya, mahasiswa dituntut untuk memainkan banyak alat.seperti kamera, video editing, bahkan YouTube sebagai media untuk menyimpan dan menyebarkan hasil dari portofolio itu.

Melalui videoe--portfolio, pebelajar mengkoleksi, menseleksi, dan 
merefleksi (collect, select, and reflect) pembelajarannya di dalam dan di luar kelas. Dengan mengikutkan $e$--portfolio ke dalam kurikulum dan menyediakan struktur pengembangan $e$--portfolio yang spesifik dalam perkuliahan, terdapat peningkatan kepedulian terhadap tingkat kemampuan pada diri pelajar dan pelajar terdorong untuk mengembangkan lebih lanjut kemampuannya.Hal ini mengindikasikan bahwa assessment portofolio dapat mendorong pertumbuhan kesadaran dan motivasi untuk berkembang.

\section{PERMASALAHAN}

Perubahan signifikan yang dihadapi pendidikan dalam dua puluh tahun terakhir telah mempengaruhi semua aspek pengajaran dan pembelajaran, termasuk untuk konteks penelitian ini, bagaimana mahasiswa terlibat dengan kajian dan teknologi yang digunakan. Melibatkan mahasiswa adalah tugas yang sulit yang dihadapi oleh semua akademisi.

Keterlibatan mahasiswa dapat didefinisikan sebagai kemauan mahasiswa, kebutuhan, keinginan dan keharusan untuk berpartisipasi dalam proses pembelajaran. Namun, banyak mahasiswa yang pasif pengetahuan, tidak pernah sepenuhnya tertarik, berpikir secara mendalam, atau benar-benar memahami apa yang dipelajari dalam kelas.

Namun disadari bahwa sistem penilaian mahasiswa masih terfokuskan pada angka hasil belajar semata bukan dari proses perubahan kemampuan mahasiswa sebagai hasil belajar. Nilai tersebut terutama dilihat darisisi kognitif, karena aspek ini yang sering dinilai oleh dosen untuk melihat penguasaan pengetahuan sebagai ukuran pencapaian hasil belajar mahasiswa.Penilaian dari sisi keterampilan atau psikomotorik masih belum diperhatikan oleh banyak pendidik.Padahal selain sisi kognitif dan afektif, sisi psikomotorik juga sangat penting untuk melihat keberhasilan mahasiswa.Salah satu teknik penilaian yang mendukung adalah penilaian portofolio menggunakan video.

Penggunaan video sebagai portofolio juga memerlukan tempat penyimpanan yang memadai. Dikatakan seperti itu karena video memerlukan ruang atau memory yang tidak sedikit. Satu video bisa berukuran lebih dari 10

MB. Jika jumlah mahasiswa cukup banyak, tentu memerlukan ruang penyimpanan yang besar. Hal ini akan membutuhkan tempat dan biaya yang tidak sedikit.

Melihat fenomena tersebut, maka diperlukan adanya teknik penilaian yang tepat, yang mencakup aspek keterampilan atau psikomotorik untuk mengukur keberhasilan peserta didik. Dalam pelaksanaan penilaian pada hakikatnya harus dilakukan secara berkala dan berkesinambungan disamping itu juga penilaian harus dapat menaksir kemampuan secara menyeluruh yang meliputi proses dan hasil pertumbuhan dan perkembangan wawasan pengetahuan, sikap dan keterampilan yang dicapai dalam belajar.

\section{LITERATURE REVIEW}

Dalam upaya mengoptimalkan penulisan jurnal, perlu dilakukan studi pustaka sebagai salah satu penerapan metode penelitian yang akan dilakukan. Manfaat dari Studi Pustaka (Literature Review) diantaranya untuk mengidentifikasikan kesenjangan (identify gaps), menghindari pembuatan ulang (reinventing the wheel), mengidentifikasikan metode yang pernah dilakukan, meneruskan penelitian 
sebelumnya, serta mengetahui orang lain yang spesialisasi dan area penelitiannya sama di bidang ini. Beberapa Literature Review tersebut adalah sebagai berikut:

1. Penelitian yang dilakukan oleh Lorraine Stefani, Robin Mason \& Chris Pegler yang berjudul "The Educational Potential of e-Portfolios: supporting personal development and reflective learning" tahun 2007. Penelitian ini membahas tentang potensi e-portfolio dalam pendidikan dengan sejumlah pendukung studi kasus dan sejumlah besar sumber daya online yang berguna dari Inggris dan di seluruh dunia. Ini adalah buku panduan praktis untuk membantu mereka yang tertarik dalam e-portfolio untuk belajar dan mengajar. Buku ini disusun dalam cara mengambil pembaca melalui tahapan e-portfolio implementasi yang akan diterapkan ke terbaru dari pengguna. Tema-tema mengikuti urutan logis dan memiliki fluiditas yang konsisten antara bab. Ini menyoroti kompleksitas dan masalah potensial pengguna mungkin menghadapi ketika menerapkan e-portfolio, sementara secara bersamaan mengidentifikasi keuntungan dan manfaat potensial untuk belajar dan mengajar yang dapat dialami dengan menggunakan $e$-portfolio.[7]

2. Penelitian yang dilakukan oleh Eka Sulistia Dewi yang berjudul "meningkatkan Kemampuan Menulis Mahasiswa dengan Pengintegrasian POWERS dalam Asessmen Portofolio Elektronik" tahun 2013. Penelitian ini merupakan penelitian tindakan kelas yang bertujuan untuk meningkatkan kemampuan mahasiswa dalam menulis dengan mengaplikasikan Strategi POWERS berbasis portopolio elektronik. Penggunaan evaluasi diri berbasis portopolio elektronik dapat meningkatkan kemampuan mahasiswa dalam proses menulis paragraf naratif dan deskriptif. Mahasiswa menjadi lebih terbuka, objektif dan tentunya mandiri.
Kelebihan dari penelitian ini adalah adanya pemanfaatan media sosial seperti facebook yang dapat memberikan dampak positif bagi para peserta didik dalam meningkatkan kemampuan menulis. Hanya saja peneliti tidak menjabarkan seperti apa pemanfaatan tersebut. [8]

3. Penelitian yang dilakukan oleh Dewa Ayu Made Suryani, mengenai Pengaruh Pendekatan Proses Berbantuan Asesmen Portofolio Elektronik Terhadap Hasil Belajar Menulis Resensi Buku Fiksi Bahasa Indonesia Ditinjai dari Kemampuan Evaluasi Diri Siswa Kelas XI SMA Negeri 1 Gianyar Tahun Pembelajaran 2011/2012. ini menunjukkan. (1) hasil belajar menulis resensi buku fiksi bahasa Indonesia antara siswa yang mengikuti pendekatan proses berbantuan asesmen portofolio elektronik lebih tinggi daripada pendekatan proses konvensional. hasil belajar menulis resensi buku fiksi bahasa Indonesia yang memiliki kemampuan evaluasi diri tinggi dengan siswa yang memiliki kemampuan evaluasi diri rendah terdapat pengaruh interaksi antara pendekatan pembelajaran dan kemampuan evaluasi diri siswa terhadap hasil belajar menulis resensi buku fiksi bahasa Indonesia. (4) Rata--rata hasil belajar menulis resensi buku fiksi bahasa Indonesia antara siswa yang mengikuti pendekatan proses berbantuan asesmen portofolio elektronik lebih tinggi daripada pendekatan proses konvensional yang memiliki kemampuan evaluasi diri tinggi dengan hasil analisis. (5) Rata--rata hasil belajar menulis resensi buku fiksi bahasa Indonesia antara siswa yang mengikuti pendekatan proses berbantuan asesmen portofolio elektronik lebih rendah daripada pendekatan proses konvensional yang memiliki kemampuan evaluasi diri rendah. kelebihan dari penelitian ini adalah, adanya uji hipotesis yang banyak dan adanya perbandingan nilai rata--rata 
sebelum dam sesudah penggunaan penilaian portofolio elektronik. [9]

4. Penelitian yang dilakukan oleh Stefania Paladini dan Xavier Pierron, mengenai Enhancing the Quantitative Skills of Business Students in a Creative Way: Assessment by Portfolio. Penelitian ini menunjukkan bahwa dari tiga keterampilan membaca, menulis dan berhitung, keterampilan berhitung adalah salah satu yang paling lemah antara siswa. Laporan ini menyimpulkan bahwa rata--rata, keterampilan berhitung di Inggris lebih miskin dari pada di banyak negara lain. Penggunaan portofolio secara bertahap menjadi populer dalam pendidikan tinggi. Sebagian besar dari alasan di balik pengenalan portofolio adalah bahwa portofolio dipandang sebagai cara mahasiswa mendorong untuk menghubungkan teori dan praktek, menerjemahkan gagasan abstrak menjadi nyata.[10]

5. Penelitian yang dilakukan oleh Untung Rahardja, Muhammad Yusup dan Erni Astuti berjudul "Penerapan Sistem Integrated Raharja Multimedia E-Portfolio (iRME) CV Online pada Perguruan Tinggi Raharja"”. Penelitian ini membahas tentang E-Portofolio adalah aplikasi yang berpusat pada pengguna canggih untuk menyimpan, mengorganisir, dan berbagi item yang mewakili pelajar individu. Namun, saat ini masih banyak orang yang belum mengetahui tentang e-portfolio, terutama bagi orang-orang yang baru lulus SMA atau sarjana yang ingin melamar pekerjaan. Mereka lebih mengenal curriculum vitae (CV). Sehingga masih banyak orang yang membuat CV secara manual, terkadang sulit untuk mengumpulkan surat-surat penting yang nantinya akan disertakan dalam sebuah $\mathrm{CV}$, membutuhkan print data yang banyak, dan hal ini membuang waktu dan biaya. Dengan memanfaatkan infrastruktur jaringan komputer dan fasilitas internet yang sudah ada, diharapkan setiap kegiatan membuat $\mathrm{CV}$ secara manual bisa beralih menjadi secara online, yaitu dengan menggunakan Integrated Raharja Multimedia Edutainment (iRME). Secara sederhana, istilah iRME dicetuskan untuk mengakomodir dan memfasilitasi Pribadi Raharja dalam upaya lifetime pengumpulan portofolio pribadi. Dalam iRME terdapat resume, banyak fitur yang menarik, dan dapat mengurangi penggunaan kertas (paperless). Sekarang, CV bukan lagi sesuatu yang kita butuhkan sesaat pada waktu sedang melamar pekerjaan.CV adalah sebuah perjalanan seumur hidup. [11]

6. Penelitian yang dilakukan oleh Ramlawati, Liliasari, dan Ana Ratna Wulan, yang berjudul Pengembangan Model Assesmen Portofolio Elektronik (APE) untuk Meningkatkan Keterampilan Generik Sains Mahasiswa. Tujuan penelitian ini adalah untuk mengembangkan model assesmen portofolio elektronik (APE) pada Praktikum Kimia Anorganik. Penelitian ini menggabungkan metode yang menekankan pada pengumpulan data secara kuantitatif dan kualitatif yang dilakukan secara bersamaan selama proses pengembangan model. Hasil angket mahasiswa menunjukkan bahwa kemampuan model APE dapat meningkatkan self-assesment, pemahaman konsep, penguasaan IT, perhatian, aktivitas, dan motivasi mahasiswa. [12]

7. Penelitian yang dilakukan oleh Cheng dan Chau, dalam jurnal berjudul Digital video for fostering self-reflection in an ePortfolio environment. Kemajuan dalam teknologi komunikasi melalui komputer telah menyebabkan minat yang kuat dalam pendidikan tinggi dalam mengeksplorasi potensi alat digital, video digital, untuk mendorong refleksi diri. Meskipun ada laporan manfaat dari video digital pada kemampuan reflektif peserta 
didik, penyelidikan sistematis bagaimana video digital dapat dimanfaatkan untuk mempromosikan refleksi diri dalam konteks e-portfolio tetap kurang dilaporkan. Hasil dari studi kasus eksplorasi skala kecil ini memberikan bukti yang mendukung penggunaan video sebagai alat reflektif dalam konteks eportfolio dan menyoroti kebutuhan untuk mempertimbangkan isu-isu pedagogis dan teknologi yang penting bagi guru, pendidik, dan pengembang eportfolio.[13]

8. Penelitian yang dilakukan oleh Dewi Immaniar, Untung Raharjda dan Reni Mulyani, dengan jurnal berjudul Audio Visual as One of the Teaching Resources on iLearning. Penelitian ini menunjukkan bahwa dengan menggunakan video dalam pembelajaran iLearning dapat membuat pelajaran lebih menarik dan tentunya dapat terserap optimal oleh mahasiswa. karena pelajaran sebelumnya lebih monoton dan tidak menarik menjadi pembelajaran tidak terserap baik oleh mahasiswa. Jurnal ini memiliki kelebihan yaitu penjabaran kelebihan dan kekurang dari penggunaan audio visual pada pembelajaran iLearning.Hanya saja kesimpulan yang ditampilkan hanya sedikit. [6]

9. Penelitian yang dilakukan oleh Trent Batson yang berjudul "The Electronic Portfolio Boom: What's it All About?'.Penelitian ini membahas tentang mengambil manfaat dari e-portfolios. Siswa tampak paling tertarik pada carae-portfolios dapat menyempurnakan resume mereka, baik sebelum maupun setelah lulus. Jika pewawancara magang atau calon majikan dapat melihat resume online yang mencakup pandangan dari pekerjaan yang sebenarnya siswa, siswa yang mungkin lebih mungkin untuk mendapatkan posisi. Siswa juga ingin melihat di mana mereka berada dalam karir kuliah mereka mengenai persyaratan. e-portfoliosbisa memfasilitasi hal ini. Ketika siswa belajar untuk tes, mereka dapat meninjau pekerjaan mereka sendiri dan membaca komentar instruktur pada pekerjaan mereka.E-portfolios akan membuat ini lebih mudah dilakukan, terutama selama semester beberapa. Jika seorang siswa ingin mentransfer, data e-portfoliodapat mempermudah proses artikulasi dengan yang lain perguruan tinggi atau universitas. Setelah lulus, mereka masih memiliki pekerjaan yang tersedia bagi mereka dalam lingkungan universitas yang didukung akan memberikan nilai yang berkelanjutan dan membantu mempertahankan hubungan dengan almamater mereka.[14]

10. Penelitian yang dilakukan oleh Reardon, Robert C / Lumsden, Jill A. I Meyer, Katie E. yang berjudul "Developing an E-Portfolio Program: Providing a Comprehensive Tool for Student Development, Reflection, and Integration” pada tahun 2005. Penelitian ini membahas tentang pengembangan portofolio mahasiswa adalah area minat dan aktivitas di banyak kampus. Program e--portfolio memiliki kegiatan yang memungkinkan siswa untuk mempelajari dan mendokumentasikan sembilan keterampilan umum yang berkaitan dengan kehidupan / pengembangan karir, yang kemudian dapat dibagi dengan pengusaha, dosen, dan pengguna dirujuk lainnya. Ini menyediakan kerangka kerja bagi siswa untuk merenungkan dan mengintegrasikan pengalaman penuh pembelajaran. Hasil dari proses evaluasi secara singkat dijelaskan, diikuti dengan peninjauan e--portfolio prestasi program, pekerjaan yang sedang berlangsung, dan kemungkinan masa depan.[15]

Dari sepuluhliterature review yang ada, telah banyak penelitian mengenai portofolio elektronik. Namun dapat disimpulkan pula bahwa belum ada 
peneliti yang secara khusus membahas mengenai video sebagai portofolio elektronik.Itulah alasan mengapa penulis tertarik untuk membahas hal tersebut. Agar nanti bisa dijadikan acuan sebagai referensi oleh dosen maupun mahasiswa.

\section{PEMECAHAN MASALAH}

Untuk dapat menyelesaikan permasalahan yang sudah dijabarkan maka diperlukan suatu solusi berupa teknik penilaian yang dapat menilai mahasiswa dari aspek keterampilan atau aspek psikomotorik. Karena aspek psikomotorik mengarah pada aktifitas fisik maka dibutuhkan juga suatu media yang dapat membantu dosen melihat aktifitas fisik mahasiswa pada saat proses pembelajaran atau sebagai hasil dari proses pembelajaran.

Teknik yang dapat mendukung dosen untuk menilai mahasiswa dari aspek psikomotorik adalah teknik penilaian portofolio. Namun portofolio yang digunakan mahasiswa adalah portofolio elektronik dengan video sebagai medianya.

Dengan portofolio elektronik dalam bentuk video dapat merangkum semua kegiatan, aktifitas fisik dan perkembangan peserta didik. Sehingga dosen dapat melihat secara keseluruhan perkembangan mahasiswa dan dapat menilai mahasiswa dari aspek keterampilan atau aspek psikomotorik.

Penilaian portofolio elektronik dengan video pada dasarnya menilai karya-karya mahasiswa secara individu pada suatu periode untuk suatu mata pelajaran.akhir suatu periode hasil karya tersebut dikumpulkan dan dinilai oleh dosen dan peserta didik. Jenis artefak atau bukti yang disajikan dalam portofolio biasanya berkisar dari tugas dalam program pendidikan dosen dalam bentuk rekaman video yang pada akhirnya akan dikumpulkan dalam batas waktu yang sudah ditentukan oleh dosen.

Untuk menyiasati besarnya tempat penyimpanan video dan biaya yang tidak murah terlebih jika jumlah mahasiswa yang banyak, maka dibutuhkan sebuah wadah yang dapat menampung banyak video dan dapat diakses secara gratis. Dalam hal ini mahasiswa dapat memanfaatkan web yang dapat menyimpan dan mengakses video secara gratis.

Salah satu web yang dapat
dimanfaatkan mahasiswa YouTube. YouTube merupakan salah satu penyedia layanan video terbesar saat ini, YouTube juga media untuk upload secara gratis. Para pengguna dapat memuat, menonton, dan berbagi klip video secara gratis.

Dengan YouTube, mahasiswa dapat dengan mudah mengupload video portofolio mereka dengan mudah tanpa terbatasi ukuran dan biaya. Dosen juga dengan mudah mengakses dan mengelompokan video yang di upload mahasiswa seseuai dengan tugas yang diberikan. Karena YouTube memberikan fasilitas berupa playlist yang dapat mengelompokan video sesuai keinginan.

Sebuah portofolio elektronik berupa video juga bisa menawarkan potensi pembelajaran baru. Penggunaan teknologi multimedia sebagai alat untuk tercapainya sebuah video portofolio telah membuat mahasiwa menguasai keterampilan baru dalam bidang multimedia.

Kelebihan dan Kekurangan Video sebagai Media e--portfolio

Dibandingan dengan proses penilaian portofolio konvensional atautradisional, penilaian dengan 
e-portfolio dengan memanfaatkan video sebagai medianya memenag memiliki beberapa kelebihan, diantaranya; (1) untuk membuat sebuah video mahasiswa dituntut untuk menggunakan beberapa alat multimedia dan softwareediting yang akan menambah pengalaman dan keterampilan baru. (2) Analisa lebihtajam, dapat membuat dosen benar--benar mengerti isi dari video dengan analisa yang lebih mendalam dan dapat membuat dosen berfikir lebih spesifik tentang isi tulisan. (3) Dosen dapat melihat jelas aspek psikomotorik mahasiswa dan keaktifan mahasiswa. (4) Proses pembuatan video akan sangat menyenangkan bagi mahasiswa sehingga mahasiswa tidak akan merasa jenuh saat mengerjakan tugas tersebut.(5) Dengan diunggahnya video mahasiswa di YouTube, secara tidak langsung mahasiswa sudah memberikan informasi kepada masyarakat umum.

Namun disamping itu, penggunaan video sebagai media $e$--portfolio juga memilik beberapa kekurangan, diantaranya, (1). Cenderung lambat dan kurang praktis dalam proses pembuatan video. (2). Alat dan software yang tidak semua mahasiswa miliki dan (3). Juga biaya produksi yang relatif mahal.

\section{IMPLEMENTASI}

\section{Pada Magics Channel milik} Perguruan Tinggi Raharja sudah sangat mewakili dan membantu dalam pengumpulan video--video portofolio yang dimiliki mahasiswa. Bahkan terdapatplaylist khusus yaitu Kegiatan Perkuliahan yang didalamnya khusus untuk menampilkan video sebagai portofolio.

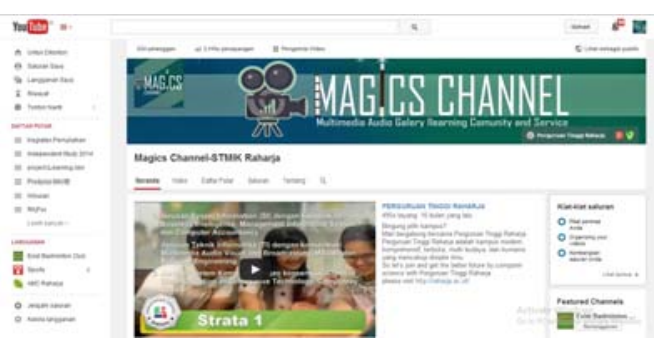

Gambar 4. Prototype Magics Channel

Mahasiswa yang mempunyai video e--portfolio dapat memasukannya kedalam playist Magics Channel dengan beberapa prosedur seperti pada flowchart dibawah ini

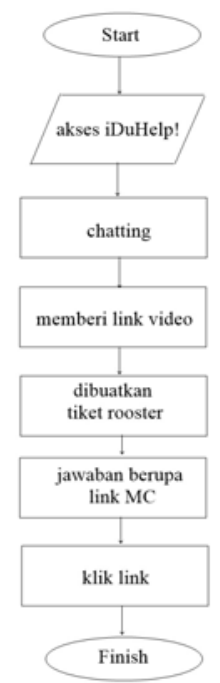

\section{Gambar 5. Flowchart Request Upload Video di Magics Channel}

Saat ini terdapat 138 video didalam Magics Channel, 30 diantaranya adala video porfolio yang diunggahmahasiswa. berikut adalah dua studi kasus e--portfolio dengan video:

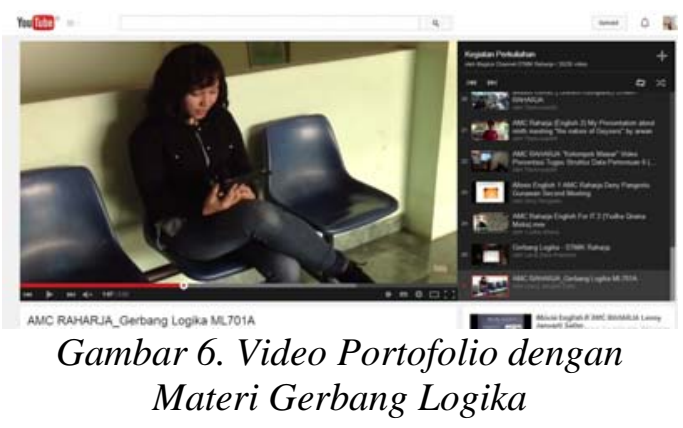


Gambar diatas adalah salah satu video yang diunggah mahasiswa sebagai portofolio.Pada judul video tersebut menjelaskan materi yang sedang diangkat dan kode mata kuliah yang menugaskan mahasiswa untuk membuat sebuah video.Dalam video tersebut terlihat mahasiswa yang sedang menjelaskan tentang gerbang logika. Dengan video seperti ini terlihat keterampilan dan pemahaman mahasiswa terhadap apa yang mereka sedang pelajari.

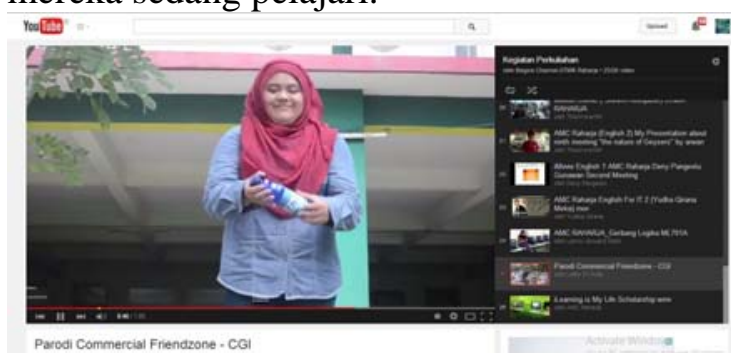

Gambar 7. Video Portofolio Tugas Pembuatan Iklan pada Mata Kuliah CGI

Selain pada gambar 1, gambar diatas juga adalah contoh video portofolio yang diunggah mahasiswa dalam tugas pembuatan iklan pada mata kuliah Computer Generated Imagery (CGI). Video ini nantinya akan dinilai oleh dosen dari beberapa point seperti, ide, alur cerita, efek, dan persentasi atau bagaimana mahasiswa menyampaikan isi dari iklan tersebut.

Untuk mengimplementasikan $e$ -portfolio dengan video pada Magics Channel adalah dengan melihat grafik statistik penayangan video pada Magics Channel beberapa minggu terakhir setelah diuploadnya video e--portfolio mahasiswa. Berikut adalah grafik yang mengilustrasikan durasi penayangan dalam satuan menit pada video $e$ -portfolio di Magics Channel.

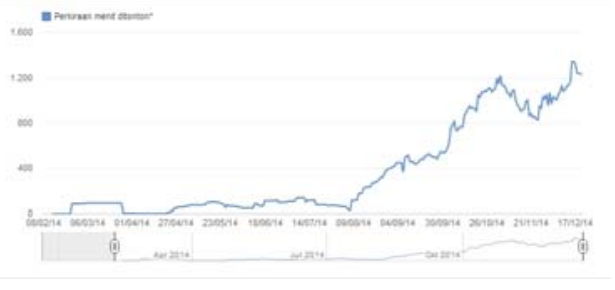

Gambar 8. Grafik Statistik Penayangan Video dalam Satuan Menit

\section{KESIMPULAN}

Dengan demikian dapat disimpulkan bahwa, penilaian adalah tugas pokok seorang dosen sebagai konsekuensi logis kegiatan pembelajaran yang telah dilaksanakan. Penilaian ini dimaksudkan untuk mengetahui dan mengambil keputusan tentang keberhasilan siswa dalam mencapai kompetensi yang telah ditetapkan. Upaya peningkatan kualitas pembelajaran dapat ditempuh melalui peningkatan kualitas sistem penilaiannya.

Penilaian hasil belajar siswa mencakup aspek kompetisi sikap, pengetahuan dan aspek keterampilan yang dilakukan secara berimbang sehingga dapat digunakan untuk menentukan posisi relatif setiap siswa terhadap standar yang telah ditetapkan. Tiap--tiap aspek penilaian (sikap, pengetahuan, dan keterampilan) memiliki karakteristik yang berbeda antara yang satu dengan yang lainnya sehingga memerlukan teknik penilaian yang berbeda yang berbeda. Teknik penilaian yang dimaksud adalah tes, observasi, penilaian diri (self assessment), penilaian antar peserta (peer assessment), penilaian kinerja (performance assessment), penilaian portofolio (portfolio assessment), dan penilaian jurnal (journal assessment).

Untuk menilai aspek psikomotorik mahasiswa, maka dosen membutuhkan teknik penilaian portofolio. Secara umum, portofolio merupakan kumpulan dokumen berupa objek penilaian yang dipakai oleh seseorang, kolompok, lembaga, organisasi atau perusahaan yang bertujuan untuk mendokumentasikan dan menilai perkembangan suatu proses. 
Mengikuti perkembangan teknologi yang ada, maka penilaian portofolio kini sudah semakin canggih dan mudah dengan menggunakan teknologi tersebut. Untuk itu saat ini portofolio sudah di kembangkan menjadi portofolio elektronik, selanjutnya disingkat $e$-portfolio, adalah koleksi digital artifak-artifak yang merepresentasikan individual, kelompok, komunitas, organisasi, atau institusi.

Komponen isie--portfolio juga sangat bervariasi tergantung pada tujuan, bentuk maupun sifat $e$--portfolio. Secara umum e--portfolio memuat data pribadi yang menggambarkan peserta didik, mata kuliah atau pendidikan informal yang diikuti, kegiatan yang diikuti baik bersifat akademis, sosial, pengalaman berorganisasi maupun bekerja serta prestasi yang dicapai termasuk tulisan, penghargaan, beasiswa dsb.

Video sebagai portofolio elektronik selain dapat mecerminkan pemahaman peserta didik terhadap suatu pembelajaran, juga dapat membuat peserta didik menguasain ketrampilan baru dalam teknologi dan multimedia.Selain itu video sebagai portofolio elektronik, mahasiwa dapat merefleksikan pembelajaran mereka, berkomunikasi dengan dosen. Mereka juga dapat merefleksikan pengetahun, pemikiran dan praktek yang semua itu adalah komponen penting untuk perkembangan keterampilan mahasiswa.

Mahasiswa juga bisa memanfaatkan internet dan web yang saat ini sudah dapat mudah diakses untuk mendukung video e--porfolio mereka. Salah satu webyang sangat mendukung video mereka adalah YouTube. Seperti halnya yang dilakukan Perguruan Tinggi Raharja dengan channel-nya di YouTube yaitu Magics Channel. Magics Channel saat ini sudah menampung banyak video portofolio dari mahasiswa. Video tersebut sudah dikelompokan dalam bentuk playlist, sehingga dosen ataupun mahasiswa lainnya dapat dengan mudah mencari dan mengakses video tersebut

\section{DAFTAR PUSTAKA}

[1] Widoyoko, Eka Putro. 2014. "Penilaian Hasil Pembelajaran di Sekolah”. Yogyakarta: Pustaka Pelajar

[2] Mardapi, Djemari. 2008. “Teknik Penyusunan Instrumen Tes dan Non Tes. Yogyakarta: Mitra Cendikia

[3] Oriondo, L.L dan Antonio, E. M.D. $1998 . \quad$ "Evaluating Educational Outcomes (Tes, Measurement and Evaluating) ". Florention St: Rex Printing company, Inc.

[4] Popham, W. J. 1995. "Classroom Assessment: What Teacher Need to Know". Boston: Allyn and Bacon

[5] Lorenzo dan Ittelson, 2005 "An Overview of E-Portfolio". Educause Learning initiative.

[6] Immaniar, Dewi, Untung Rahardja dan Reni Mulyani. 2013. "Audio Visual as One of Teaching Resources on Teaching". CCIT Journal Vol. 5, ISSN 1978-8282

[7] Stefani, Lorraine, Robin Mason dan Chris Pegler. "The Educational Potential of e-Portfolio: Suporting personal development and reflective learning ". 2007 London: Routledge, ISBN-13: 978-0415412148

[8] Dewi, Eka Sulistia. 2013. "meningkatkan Kemampuan Menulis Mahasiswa dengan Pengintegrasian POWERS dalam Asessmen Portofolio Elektronik" Vol. 2, No. 2, ISSN: 2303-288X

[9] Suryani, Dewa Made. 2011. "Pengaruh Pendekatan Proses Berbantuan Asesmen Portofolio Elektronik Terhadap Hasil Belajar Menulis Resensi Buku Fiksi Bahasa Indonesia Ditinjai dari Kemampuan 
Evaluasi Diri Siswa Kelas XI SMA Negeri 1 Gianyar Tahun Pembelajaran 2011/2012”

[10] Paladini, Stefani. 2010. "Enhancing the Quantitative Skills of Business Students in a Creative Way: Assessment by Portfolio" Coventry University

[11]Rahardja, Untung, Muhammad Yusuf dan Erni Astuti. 2014 "Penerapan Sistem Integrated Raharja Multimedia E-Portfolio (iRME) CV Online pada Perguruan Tinggi Raharja" CCIT Journal Vol.7 No.2 ISSN: 1978 - 8282

[12], Liliasari dan Ana Ratna Wulan. 2012. "Pengembangan Model Assesmen Portofolio Elektronik (APE) untuk Meningkatkan Keterampilan Generik Sains Mahasiswa” Jurnal Chemica Vol. 13 Nomor 1

[13]Cheng dan Chau. 2009. "Digital video for fostering self-reflection in an ePortfolio environment" Learning, Media and Technology: Vol. 34, No. 4, pp. 337-350

[14] Batson, Trent. 2003. "The Electronic Portfolio Boom: What's it All About?".Syllabus, 16 (5).

[15] Reardon, Robert C, Lumsden, Jill A. dan Meyer, Katie E. 2005. "Developing an E-Portfolio Program: Providing a Comprehensive Tool for Student Development, Reflection, and Integration" NASPA Journal, Vol. 42, no. 3 